\title{
Antifungal activity of flavonoids and modulation of expression of genes of fatty acid synthesis in the dermatophyte Trichophyton rubrum
}

\author{
Tamires Aparecida Bitencourt, Tatiana TakahasiKomoto, Mozart Marins, Ana Lúcia Fachin \\ From 5th Congress of the Brazilian Biotechnology Society (SBBIOTEC) \\ Florianópolis, Brazil. 10-14 November 2013
}

\section{Background}

Dermatophytosis are fungal infections caused by keratinophilic fungi known as dermatophytes and classified in three genera: Trichophyton, Epidermophyton and Microsporum. Trichophyton rubrum is the most frequent species associated to dermatophytosis worldwide [1]. The infections caused by dermatophytes are not lethal, but are difficult to treat and uncomfortable. In the case of T. rubrum, they tend to be chronic, and although the superficial infections are more common, cases of deep infection have been reported in immunocompromised patients [2][3]. The number of antifungal drugs are still limited, and the acquired resistance for some of clinical antifungal have been shown as well as the side effects that have been promoted by them. Reasons for the challenge in development of new antifungal drugs are the similarities shared by fungal and mammalian cells and the lack of knowledge about the biology of these pathogens. Recent evidences have shown that the fatty acid sinthase (FAS) is an interesting antifungal target [4] because of marked differences between human and fungal cells. The aim of this study was to evaluate the antifungal activity of four flavonoids described as FAS inhibitors and verify the modulation of genes in the pathway of fatty acid synthesis in $T$. rubrum growth in presence of the most effective one as FAS inhibitor.

\section{Methods}

The susceptibility assay was carried out using the microdilution test in RPMI medium in 96-well plates with the flavonoids quercetin, ellagic acid, galangin and genistein in a range of $1000-1.9 \mu \mathrm{g} / \mathrm{mL}$ toward the strain ATCC MYA-3108 of T. rubrum [5]. The modulation of genes

University of Ribeirão Preto, Ribeirão Preto, São Paulo,14096900, Brazil fatty acid synthesis(FAS 1p, FAS 2p subunits), acetyl-COA carboxylase $2 p$ subunity and fatty acid transporter protein (FAT1) was analyzed by quantitative PCR using Sybr Green after $16 \mathrm{~h}$ of incubation of strain of T.rubrum with MIC of quercetin in liquid Sabouraud medium.

\section{Results and conclusion}

Quercetin showed the most effective antifungal activity with MIC of $125 \mu \mathrm{g} / \mathrm{mL}$, ellagic acid presented MIC of $250 \mu \mathrm{g} / \mathrm{mL}$, galangin and genistein were ineffective toward T.rubrum (MIC $>1000 \mu \mathrm{g} / \mathrm{mL}$ ). The positive controls fluconazole and cerulenin presented MICs of 63 and $125 \mu \mathrm{g} / \mathrm{mL}$, respectively. The analyse of gene expression of the fatty acid synthetic pathway showed the majority of the genes were downregulated by quercetin, fluconazole and cerulenin. However, cerulenin caused a low upregulation of $F A S 2 \mathrm{p}$ gene. Thus, the results suggest the activity of quercetin could be due the modulation of genes of the pathway of fatty acid synthesis, which is a fungal specific target for development of antifungal drugs.

\section{Acknowledgements}

This study was supported by grants from Fundação de Amparo a Pesquisa do Estado de São Paulo (2012/02920-7 and 2009/12419-0) and CAPES.

\section{Published: 1 October 2014}

\section{References}

1. Martinez DA, Oliver BG, Graser Y, Goldberg JM, Li W, Martinez-Rossi NM, Monod M, Shelest E, Barton RC, Birch E, et al: Comparative genome analysis of Trichophyton rubrum and related dermatophytes reveals candidate genes involved in infection. mBio 2012, 3:1-14.

2. Achterman RR, White TC: Dermatophyte virulence factors: identifying and analyzing genes that may contribute to chronic or acute skin infections. International journal of microbiology 2012, 2012:1-8.

3. Nir-Paz R, Elinav H, Pierard GE, Walker D, Maly A, Shapiro M, Barton RC, Polacheck I: Deep infection by Trichophyton rubrum in an immunocompromised patient. Journal of clinical microbiology 2003 41:5298-5301. 
4. Li XC, Joshi AS, EISohly HN, Khan SI, Jacob MR, Zhang Z, Khan IA, Ferreira D, Walker LA, Broedel SE, et al: Fatty acid synthase inhibitors from plants: isolation, structure elucidation, and SAR studies. Journal of natural products 2002, 65:1909-1914.

5. Rex JH, Alexander BD, Arthington-Skaggs B, Brown SD, Chaturveli V, Espinel-Ingroff A, Ghannoum MA, Knapp CC, Motyl MR, Ostrosky-Zeichner L, et al: Reference method for broth dilution antifungal susceptibility testing of conidium forming filamentous fungi. NCCLS 2008, 28:1-9.

doi:10.1186/1753-6561-8-S4-P53

Cite this article as: Bitencourt et al: Antifungal activity of flavonoids and modulation of expression of genes of fatty acid synthesis in the

dermatophyte Trichophyton rubrum. BMC Proceedings 2014 8(Suppl 4):P53.

\section{Submit your next manuscript to BioMed Central} and take full advantage of:

- Convenient online submission

- Thorough peer review

- No space constraints or color figure charges

- Immediate publication on acceptance

- Inclusion in PubMed, CAS, Scopus and Google Scholar

- Research which is freely available for redistribution

Submit your manuscript at www.biomedcentral.com/submit
Ciomed Central 